\title{
Comparison of dual acting drugs and conventional NSAIDs towards parameters of NO-synthase system and oxidative stress in mucosal membrane of large intestine of rats with experimental ulcerative colitis
}

\author{
A. Ya. Sklyarov', R. B. Lesyk², N. B. Panasyuk', I. S. Fomenko', D. Ya. Havrylyuk ${ }^{2}$ \\ ${ }^{1}$ Department of Biochemistry Danylo Halytsky Lviv National Medical University \\ 69, Pekarska St., Lviv, Ukraine, 79010 \\ ${ }^{2}$ Department of Pharmaceutical, Organic and Bioorganic Chemistry Danylo Halytsky Lviv National Medical University \\ 69, Pekarska St., Lviv, Ukraine, 79010 \\ sklyarov@meduniv.lviv.ua
}

\begin{abstract}
Aim was to compare the action of 2A5DHT compound (dual COX-2/5-LOX inhibitor) and conventional non-steroidal anti-inflammatory drugs towards parameters of nitric oxide (NO) system and intensity of oxidative stress in the mucous membrane of the large intestine (MMLI) in rats with experimental ulcerative colitis. Methods. Ulcerative colitis was induced by administration of acetic acid. The activity of NOsynthases, content of $N O$, and parameters of lipoperoxidation processes were measured in MMLI. Results. COX-2/5-LOX inhibition by 2A5DHT compound did not cause considerable destructive changes of the $M M L I$ of rats. The activity of inducible nitric oxide synthase (iNOS) declined more than 2 fold as compared to their activity in colitis. The intensity of lipoperoxidation processes was found to be much lower than under the separate effect of celecoxib or indomethacine. Conclusions. Dual COX-2/5-LOX inhibition by $2 A 5 D H T$ has a significant cytoprotective effect in MMLI that is accompanied by reduction of oxidative stress and activity of NO-synthases. The substance $2 A 5 D H T$ significantly overexceeds the cytoprotective effects of both selective and non-selective COX/LOX inhibitors and can be used in the treatment of inflammatory bowel disease.
\end{abstract}

Keywords: cyclooxygenase-2, 5-lipooxygenase, nitric oxide, lipoperoxidation, ulcerative colitis.

Introduction. Although the etiology of inflammatory bowel disease (IBD) remains unknown, mounting evidence implicates increased eicosanoids production in the inflammatory process of this disease [1]. Prostaglandines (PGs), thromboxanes, and leukotriens (LTs) are collectively referred to as eicosanoids. PGs are produced via the cyclooxygenase (COX) pathway and exhibit both pro- and anti-inflammatory effects. COX is now known to exist in three isoforms: COX-1, COX-2, and COX-3. COX-1 is constitutively expressed in the large intestine under physiological conditions. At the

\footnotetext{
(c) Institute of Molecular Biology and Genetics NAS of Ukraine, 2011
}

same time, COX-2 is also expressed under the normal conditions in the interstitial tissue, epithelial cells, and neurons of submucous and intermuscular plexuses. PGs synthesized by COX-1, provide for the processes of water and electrolyte transport, vasodilatation, proliferation, and intercellular integration. Considerable amounts of PGs synthesized by COX-2 are involved in the inflammatory process [2]. Sustained inhibition of both COX isoforms by nonsteroidal anti-inflammatory drugs (NSAIDs) can cause intestinal ulceration in humans and laboratory animals. However, clinical and experimental studies indicate that selective COX-2 inhibitors are less ulcerogenic than nonspecific COX in- 
hibitors (e. g. indomethacin) [3]. For now it is generally accepted that people with IBD should avoid NSAIDs.

Lipooxygenase (LOX) pathway also plays an important role in inflammatory processes in IBD. Leukotrienes (LTs) and lipoxins produced via LOX activity are associated with leukocytes activation and adhesion to vascular endothelium. In ulcerative colitis and Crohn's disease LTB4 is considered to be linked to inflammatory lesions created by neutrophils observed in the colonic and small bowel mucosa. Several experimental data support the postulate that COX inhibition with NSAIDs, besides causing a reduction in the synthesis of PGs, diverts arachidonate to the 5-LOX pathway, thus increasing the formation of LTs. This causes vasoconstriction and increases the formation of reactive oxygen radicals from the peroxidative cleavage of hydroxyeicosatetraenoic acids, which cause further mucosal injury [4].

Besides pro-inflammatory systems COX/PGs and LOX/LTs, one more very important system involved in the development of IBD is nitric oxide (NO) system. The destructive changes of the intestinal mucosa are associated with increased numbers of active forms of oxygen, enhanced synthesis of NO, expression of inducible nitric oxide synthase (iNOS) by epithelial cells, macrophages, and neutrophil infiltration into the damaged mucous membrane. Recent investigations have established a close interrelationship existing between iNOS and COX-2 [5].

In the past few decades several compounds have been developed to block both COX and 5-LOX. Dual $\mathrm{COX} / \mathrm{LOX}$ inhibitors constitute a valuable alternative to classical NSAIDs and selective COX-2 inhibitors for treatment of inflammatory diseases. Moreover, they appear to be almost exempt from gastrointestinal toxicity $[6,7]$. One of the most potent dual inhibitors is darbufelone (with the active substance 2A5DHT - 2-amino-5-(3,5-ditertbutyl-4-hydroxybenzylidene)-thiazol4-one). In a randomized, double blind, rising singleand multiple-dose study in healthy volunteers, it was well tolerated up to the oral daily dose of $100 \mathrm{mg}$ [4].

The role of COX/PGs and LOX/LTs systems in the pathogenesis of IBD so far remains disputable and leaves much to be elucidated. That is why the aim of this research was to compare the action of nonspecific COX inhibitor indomethacine, $\mathrm{COX}-2$ selective inhibitor ce- lecoxib, 5-LOX blocker AA-861 and 2A5DHT, which is the active substance of dual COX-2/5-LOX inhibitor 2A5DHT on indexes of NO-synthase system and intensity of oxidative stress in the mucous membrane of the large intestine (MMLI) under condition of experimental ulcerative colitis.

Materials and methods. Animals. The experimental protocols were approved by the Ethical Committee of Lviv National Medical University (Ukraine). Male albino rats weighing $200-250 \mathrm{~g}$ were used. The animals were kept under artificial 12-hour light/dark cycle at a constant temperature of $21-22{ }^{\circ} \mathrm{C}$ and fed on a standard rat chow and water ad libitum. All rats were fasted $24 \mathrm{~h}$ prior to the experimental procedure.

The study comprised of the following series of experiments: 1 - intact animals were used as controls $(n=$ $=10) ; 2-$ ulcerogenic lesions in rats were induced by $4 \%$ acetic acid as previously described $(n=10)$ [8]; 3 non-selective COX inhibitor, indomethacin («Sigma», USA) was introduced in a dose of $10 \mathrm{mg} / \mathrm{kg}(n=8) ; 4$ selective COX-2 inhibitor, celecoxib («Arterium», Ukraine) was introduced in a dose of $10 \mathrm{mg} / \mathrm{kg}(n=10)$; 5 - 5-LOX blocker, AA-861 («Wako», Japan) was introduced in a dose of $50 \mathrm{mg} / \mathrm{kg}(n=8) ; 6$ - dual COX2/5-LOX inhibitor synthesized in the laboratory of Department of Pharmaceutical, Organic and Bioorganic Chemistry Danylo Halytsky Lviv National Medical University -2 A5DHT was introduced in a dose of $10 \mathrm{mg} / \mathrm{kg}(n=8)$. All preparations (celecoxib, indomethacin, AA-861 and 2A5DHT) were administered in $1 \mathrm{ml}$ volumes per os $1 \mathrm{~h}$ before and $24 \mathrm{~h}$ after the intrarectal application of acetic acid.

Under general anesthesia, rats were sacrificed by decapitation and $10 \mathrm{~cm}$ of the distal colon were excised, freed from adherent adipose tissue and opened longitudinally. After washing the mucosa with saline, mucosal injury (macroscopically) was assessed using the grading scale of Morris et al. [9]. No damage (score 0); localized hyperemia but no ulcers (score 1); linear ulcer with no significant inflammation (score 2); linear ulcer with inflammation at one site (score 3); two or more sites of ulceration and inflammation (score 4); two or more sites of ulceration and inflammation or one major site of inflammation and ulceration extending $>1 \mathrm{~cm}$ along the length of the colon (score 5). Colonic tissue samples were homogenized in phosphate buffer $\mathrm{pH} 6.0$ 

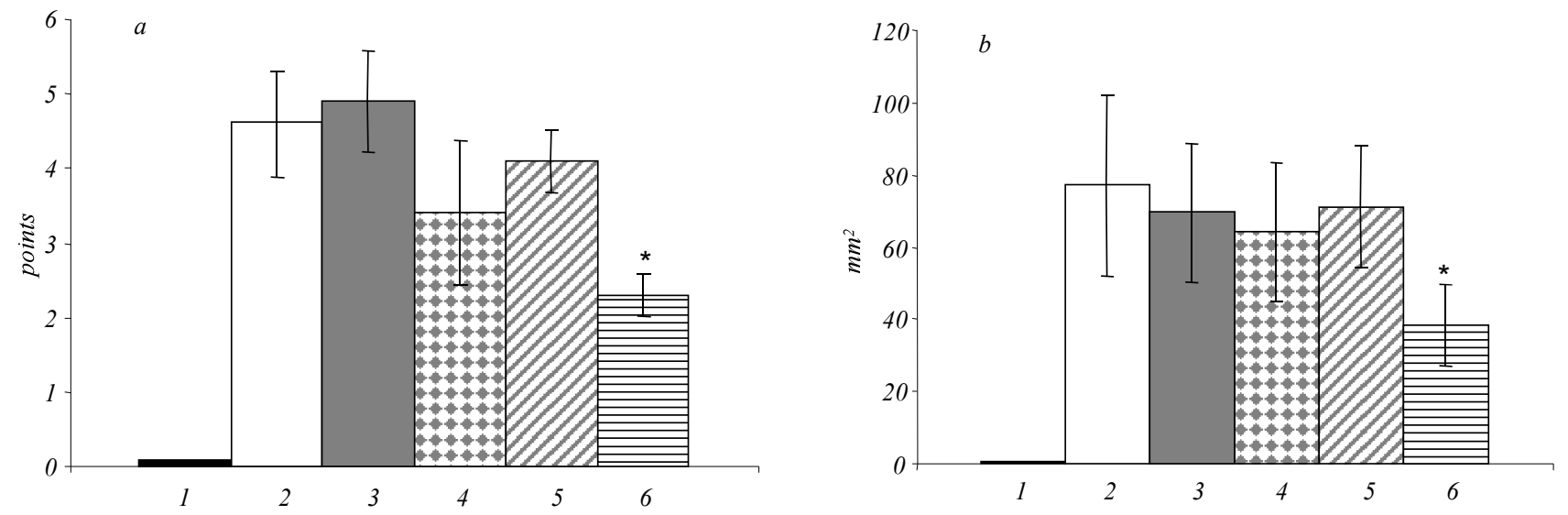

The character (in score) $-a$ and the area $-b$ of the structure-hemorrhagic damage of the MMLI: 1 - control; 2 - in rats with ulcerative colitis; 3 resulting from introduction of non-selective COX inhibitor indomethacin, at the colitis; 5 - resulting from introduction of 5-LOX blocker, AA-861 at the background of ulcerative colitis; 6 - resulting from introduction of dual COX-2/5-LOX inhibitor, 2A5DHT compound at the background of ulcerative colitis. $* \mathrm{P}<0.05$ versus the indexes in colitis

$1: 4$ and centrifuged at $5000 \mathrm{rpm}$, supernatant was used to determine values of biochemical parameters.

Determination of NO-system in colonic tissues. The content of NO in homogenate was determined as nitrites by the method of Green et al. [10]. The absorbance was read in a Stat fax at $550 \mathrm{~nm}$. NO concentration was expressed as $\mu \mathrm{mol} / \mathrm{g}$. NO-synthases (general NOS, iNOS, and endothelial NOS - eNOS) activity was measured by the method described in detail [11]. NOS activity was expressed in $\mathrm{nmol} \mathrm{NADPH} \cdot \mathrm{min}^{-1} \cdot \mathrm{mg}^{-1}$ of protein.

Measurement of L-arginine in plasma samples. The level of L-arginine in plasma samples was measured according to the procedure of Alejnikova [12]. Plasma L-arginine level was expressed as $\mu \mathrm{g} / \mathrm{ml}$.

Lipid peroxidation determination. Lipid peroxidation level was expressed as MDA (malonic dialdehyde) concentration in homogenates of MMLI. It was measured according to the procedure of Timirbulatow et al. [13]. MDA levels were expressed as $\mu \mathrm{mol} / \mathrm{g}$. Catalase (CAT) activity was determined by measuring of the decrease in hydrogen peroxide concentration at $410 \mathrm{~nm}$ by the Korolyuk method [14].

Colon mucosal catalase activity was expressed in $\mu \mathrm{mol} \mathrm{H}_{2} \mathrm{O}_{2} \cdot \mathrm{min}^{-1} \cdot \mathrm{mg}^{-1}$ of protein. Activity of superoxide dismutase (SOD) was determined by the reaction of reduction of nitrotetrazoliume blue to nitroformazan [15]. SOD activity was expressed in $\mu \mathrm{mol} \cdot \mathrm{min}^{-1} \cdot \mathrm{mg}^{-1}$ of protein.
Statistics. Experimental results were analyzed by ANOVA and $t$-tests for multiple comparisons between groups. The data was finally expressed as mean \pm standard deviation. $\mathrm{P}$ value less than 0.05 was considered statistically significant.

Results and discussion. In our study, injection of $4 \%$ solution of acetic acid induced lesions, manifested by ulcerative colitis, erosions and hemorrhages, with a total area of $77.2 \pm 25.1 \mathrm{~mm}^{2}$. Character of the structure-hemorrhagic damage of the MMLI had in score $4.6 \pm$ \pm 0.69 (Figure).

Ulcerative colitis in the MMLI was associated with enhancement of the activity of NO-synthases: activity of general NOS enhanced more than threefold (from $0.88 \pm 0.09$ to $2.68 \pm 0.58 \mu \mathrm{mol} \cdot \mathrm{min}^{-1} \cdot \mathrm{g}^{-1}$ ), activity of eNOS - by $58 \%$, and activity of iNOS - 6.9fold $(\mathrm{P}<0.01)$. In colonic mucosa content of NO increased by $64 \%$ and, concomitantly, content of L-arginine in blood decreased by $51 \%$ (from $37.8 \pm 12.8$ to $18.53 \pm 4.98 \mathrm{mg} / \mathrm{ml}$ ) (Tabl. 1).

MMLI, affected with ulcerative colitis, was subjected to the following changes: enhanced activity of lipoperoxidation processes manifested by a steep rise of MDA content - by $116 \%$ (from $255.5 \pm 24.3$ to $556.3 \pm$ $\pm 15.7 \mu \mathrm{mol} / \mathrm{g})(\mathrm{P}<0.01)$, at that, SOD activity enhanced by $71 \%(\mathrm{P}<0.01)$, and catalase activity - by $54 \%$ $(\mathrm{P}<0.01)$ (Tabl. 2).

The destructive changes the intestinal mucosa are subjected due to IBD and ulcerative colitis is associated 
Table 1

The activity of NO-synthases, content of NO in MMLI and L-arginine in blood under conditions of separate and combined inhibition of COX-1,COX-2 and 5-LOX at the background of ulcerative colitis

\begin{tabular}{|c|c|c|c|c|c|}
\hline Groups of animals & $\mathrm{NO}, \mu \mathrm{mol} / \mathrm{g}$ & $\begin{array}{l}\text { iNOS, } \mathrm{nmol} \cdot \mathrm{min}^{-1} \cdot \mathrm{g}^{-1} \\
\text { of protein }\end{array}$ & $\begin{array}{l}\text { eNOS, } \mathrm{nmol} \cdot \mathrm{min}^{-1} \cdot \mathrm{g}^{-1} \\
\text { of protein }\end{array}$ & 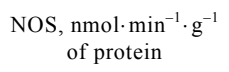 & L-arginine, $\mu \mathrm{g} / \mathrm{ml}$ \\
\hline Control group & $1.37 \pm 0.14$ & $0.239 \pm 0.07$ & $0.65 \pm 0.09$ & $0.88 \pm 0.09$ & $37.8 \pm 12.8$ \\
\hline $4 \%$ acetic acid & $2.37 \pm 0.43$ & $1.65 \pm 0.50$ & $1.03 \pm 0.32$ & $2.68 \pm 0.58$ & $18.6 \pm 4.7$ \\
\hline $4 \%$ acetic acid + indomethacin & $1.96 \pm 0.11$ & $1.64 \pm 0.37$ & $0.49 \pm 0.27$ & $2.13 \pm 0.52$ & $20.1 \pm 6.7$ \\
\hline $4 \%$ acetic acid + celecoxib & $1.89 \pm 0.27$ & $0.898 \pm 0.03 *$ & $0.623 \pm 0,10$ & $1.52 \pm 0,12 *$ & $22.4 \pm 3.8^{*}$ \\
\hline $4 \%$ acetic acid + AA- 861 & $2.12 \pm 0.28$ & $0.91 \pm 0.13$ & $0.73 \pm 0.15$ & $1.64 \pm 0.39$ & $23.1 \pm 8.4$ \\
\hline $4 \%$ acetic acid $+2 \mathrm{~A} 5 \mathrm{DHT}$ & $2.10 \pm 0.18$ & $0.48 \pm 0.15^{*}$ & $0.59 \pm 0.17$ & $1.08 \pm 0.30 *$ & $26.3 \pm 3.0$ \\
\hline
\end{tabular}

$\mathrm{N}$ o t e. $* \mathrm{P}<0.05$

Table 2

The parameters of lipoperoxidation and the activity of SOD and CAT under conditions of separate and combined inhibition of COX-1, COX-2 and 5-LOX at the background of ulcerative colitis

\begin{tabular}{|c|c|c|c|}
\hline Groups of animals & $\mathrm{MDA}, \mu \mathrm{mol} / \mathrm{g}$ & $\mathrm{SOD}, \mu \mathrm{mol} \cdot \mathrm{min}^{-1} \cdot \mathrm{mg}^{-1}$ of protein & $\mathrm{CAT}, \mu \mathrm{mol} \mathrm{H}_{2} \mathrm{O}_{2} \cdot \mathrm{min}^{-1} \cdot \mathrm{mg}^{-1}$ of protein \\
\hline Control group & $255.5 \pm 24.3$ & $18.8 \pm 5.5$ & $2.42 \pm 0.3$ \\
\hline $4 \%$ acetic acid & $556.3 \pm 15.7$ & $32.0 \pm 4.5$ & $3.72 \pm 0.54$ \\
\hline $4 \%$ acetic acid + indomethacin & $543.4 \pm 61.2$ & $26.7 \pm 3.1$ & $3.54 \pm 0.49$ \\
\hline $4 \%$ acetic acid + celecoxib & $444.0 \pm 58.4 *$ & $17.2 \pm 1.8^{*}$ & $3.18 \pm 0.98^{*}$ \\
\hline $4 \%$ acetic acid + AA- 861 & $543.6 \pm 25.7$ & $23.4 \pm 2.4$ & $3.34 \pm 0.31$ \\
\hline $4 \%$ acetic acid $+2 \mathrm{~A} 5 \mathrm{DHT}$ & $334 \pm 12.4 *$ & $21.2 \pm 1.9^{*}$ & $3.36 \pm 0.8$ \\
\hline
\end{tabular}

$\mathrm{N}$ o t e. $* \mathrm{P}<0.05$.

with increased numbers of active forms of oxygen, enhanced synthesis of NO, expression of iNOS by epithelial cells, macrophages, and neutrophil infiltration into the damaged mucous membrane [16].

In the present study, development of ulcerative colitis induced by per rectum introduction of acetic acid was accompanied by the characteristic destructive changes in the MMLI, enhanced processes of lipoperoxidation, increased content of NO, and considerable activation of iNOS. Due to activation of NO-synthases, concentration of L-arginine, the substrate for NOS, in the plasma of blood decreased and content of NO in the MMLI increased.

IBD is characterized by a chronic intestinal inflammatory process with various components contributing to the pathogenesis of the disease including different factors such as stress and use of NSAIDS. NSAIDS are among the most commonly used medications for the treatment of various inflammatory conditions. The main factor limiting NSAIDs use is the concern for the development of gastrointestinal toxicity including mucosal injury.

Several retrospective and cohort studies have implicated NSAIDs in the onset or exacerbation of IBD. It was shown, that injection of nonselective COX inhibitors, the NSAIDs - indomethacin, naprofen, and diclofenac caused destructive changes in the small intestine of laboratory animals. For this reason, the content of PGE2 considerably decreased which is evidence that deficiency of PGs is the key factor whose impact results in damage to the small intestine induced by the effect of NSAIDs [2]. The decrease of PGs synthesis in the site of inflammation considerably correlated with the reduction of COX-1 activity, but not COX-2 [17]. It was acertained that $\mathrm{COX}-1$, but not COX-2, plays a role in maintaining the mucosal integrity [18]. 
In our investigation, non-selective COX inhibition by indomethacin resulted in significantly worse colitis as compared with acetic acid colitis alone. Nevertheless parameters of NO-synthase system and oxidative stress were practically the same like in ulcerative colitis.

Many reports showed that COX-2 is the main form responsible for PGE2 production at the site of inflammation [17]. Nevertheless the role of COX-2 in the development of ulcerative lesions so far remains disputable. On the one hand, it was previously reported that inhibition of COX-2 aggravated experimentally-induced colonic lesion, that caused considerable inhibition of biosynthesis of PGs and increased area of lesions in colon $[19,20]$. On the other hand, it was shown that under inhibition of COX-2 with celecoxib, damage to the MMLI was reduced as well as neutrophilic infiltration and the level of IL $1 \beta$. Celecoxib caused a substantial reduction of the degree of colonic injury, rose the myeloperoxidase activity in mucosa and increased the tissue level of MDA [21].

In our investigations it was established that $\mathrm{COX}-2$ inhibitor celecoxib decreased the area of lesions of colonic mucosa, separate erosions and hemorrhages were localized in the rugae. Under this condition activity of iNOS, eNOS and NO content decreased, L-arginine concentration in the blood plasma was increased. The content of MDA and SOD activity decreased. Therefore, as the COX-2 inhibition led to the increase of cytoprotective processes, it suggests that PGs, produced by COX-2, are associated with inflammation and have many proinflammatory activities that could contribute to symptoms of ulcerative colitis.

Both the conventional NSAIDs and the selective COX-2 inhibitors primarily exert their activity by reducing the production of PGs induced in inflammatory process. In recent years, it has been clarified that PGs synthesis is only one part of arachidonic acid pathway, this precursor being a substrate that gives rise to many other lipid mediators, such as the LTs and the lipoxins. LTs themselves have a major role in the development and persistence of inflammatory process in MMLI [6]. Enhanced activation of LOX and increased content of LTs are characteristic of ulcerative colitis [22]. A steep rise in the content of proinflammatory LTs $-\mathrm{C} 4, \mathrm{D} 4$, and $\mathrm{B} 4$, released predominantly by macrophages, mo- nocytes, eosinophils, and mast cells, is observed in experimental ulcerative colitis in the MMLI. Although in a number of research works a higher production of LTs in colitis has been reported [23], but it was not always accompanied by an increased production of PGE2.

In our investigations it was shown that administration of 5-LOX inhibitor AA-861 at the background of colitis had not effect on the severity of lesions. Activity of NO-synthases had a tendency to decrease, whereas iNOS activity was declined by $44 \%$, compared to their activity in colitis. Contents of NO and MDA also showed a tendency to decrease. Hence, under condition of LOX-5 inhibition the intensity of lipoperoxidation processes remained high as well as NOS activity. This suggests that the product of 5-LOX reaction - LTB4 didn't play a central role in pathogenesis of experimental ulcerative colitis.

In recent years it was shown, that both metabolites of arachidonic acid PGs and LTs have complementary effects in inflammation. We suggested that blockage both LTs and PGs production might have synergic effects and achieve optimal anti-inflammatory activity. Dual inhibition of COX-2 and 5-LOX may limit the vascular changes seen during inflammation and leukocytes induced damage of MMLI [6].

Dual COX-2/5-LOX inhibition with compound 2A5DHT displayed significant cytoprotective effect. Microscopy detected separate hemorrhages with the absence of considerable destructive changes of the MMLI. Activity of iNOS declined more than 2 fold, and total activity of NO-synthases decreased by $56 \%$ as compared to their activity in colitis. Content of $\mathrm{NO}$ manifested a tendency to decrease. Intensity of lipoperoxidation processes were determined much lower than under the effect of celecoxib and indomethacine, MDA concentration declined by $40 \%$.

For this reason, dual COX-2/5-LOX inhibition by 2A5DHT has a significant cytoprotective effect in rats with experimental ulcerative colitis and was accompanied by reduction of oxidative stress and activity of NO-synthases in MMLI.

Conclusions. In an experimental model of inflammatory bowel disease, nonspecific COX inhibition with indomethacin resulted in a significantly worse clinical condition, as compared with acetic acid colitis alone. Under COX-2 inhibition with celecoxib cyto- 


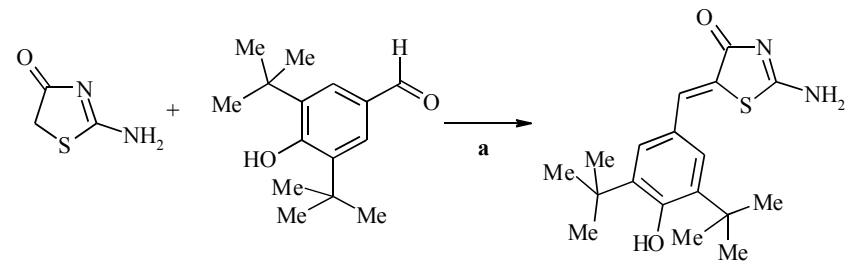

Synthesis of 2-amino-5-(3,5-ditertbutyl-4-hydroxybenzylidene)-thia zol-4-one (2A5DHT). Reagents, conditions and yields: $a-\mathrm{AcONa}$, $\mathrm{AcOH}$, reflux $3 \mathrm{~h}, 68 \%$

protective processes in MMLI were enhanced and oxidative stress levels were reduced.

5-LOX inhibition with AA-861 revealed no significant effect on structure-hemorrhagic lesions in MMLI caused by the administration of $4 \%$ acetic acid. Concomitantly, iNOS activity was reduced, MDA content displayed a tendency to the decrease.

Dual COX-2/5-LOX inhibition with 2A5DHT compound displayed significant cytoprotective effect, manifested by the decreased area of the MMLI lesions, and the decline of NO-synthases activities and the intensity of lipoperoxidation processes. The substance 2A5DHT significantly overexceeds the cytoprotective effects of both selective and non-selective COX/LOX inhibitors and can be used in the treatment of inflammatory bowel disease.

Addendum. Synthesis of 2A5DHT. The starting 2aminothiazol-4-one was obtained according to method described previously [24].

The elemental analyses $(\mathrm{C}, \mathrm{H}, \mathrm{N})$ were performed using the Perkin-Elmer $2400 \mathrm{CHN}$ analyzer. Analyses indicated by the symbols of the elements or functions were within $\pm 0.4 \%$ of the theoretical values. The ${ }^{1} \mathrm{H}$ NMR spectra were recorded on Varian Gemini $400 \mathrm{MHz}$ in DMSO- $\mathrm{d}_{6}+\mathrm{CCl}_{4}$ mixture using tetramethylsilane (TMS) as an internal standard. Chemical shifts are reported in ppm units with use of $\delta$ scale.

Mixtures of 2-aminothiazol-4-one (5 mmol), 3,5ditertbutyl-4-hydroxybenzaldehyde $(5.5 \mathrm{mmol})$ and anhydrous sodium acetate $(5 \mathrm{mmol})$ were refluxed for $3 \mathrm{~h}$ in glacial acetic acid $(10 \mathrm{ml})$. Obtained powder was filtered off, washed with water and recrystallized with glacial acetic acid.

Yield $68 \%,{ }^{1} \mathrm{H}$ NMR $\left(300 \mathrm{MHz}, \mathrm{DMSO}-d_{6}+\right.$ $\left.+\mathrm{CCl}_{4}\right): \delta[\mathrm{ppm}]$ 9.81, 9.30, 9.03 (s, br. s, s, 2H, $\mathrm{NH}_{2}$ );
7.67 (s, 1H, OH); 7.53 (s, 1H, CH); 7.35 (s, 2H, arom); $1.40(\mathrm{~s}, 18 \mathrm{H}, 2 \cdot t-\mathrm{Bu})$.

Acknowledgements. The authors would like to thank Professor Hiroshi Satoh (the Department of Veterinary Medicine, Faculty of Agriculture, Tottori University, Japan) for providing the blocker of 5-lipooxigenase - AA-861.

\section{А. Я. Скляров, Р. Б. Лесик, Н. Б. Панасюк, І. С. Фоменеко, Д. Я. Гаврилюк}

Порівняння впливу препаратів подвійної дії та традиційних НПЗ3 на показники системи NO-синтази і оксидативного стресу у слизовій оболонці товстої кишки щурів 3 експериментальним виразковим колітом

Резюме

Мета. Порівняти вплив сполуки 2A5DНТ (інгібітора ЦОГ2/5-ЛОГ) та дію традииійних нестероїдних протизапальних засобів на показники NO-синтазної системи та оксидативного стресу у слизовій оболонці товстої кишки (СОТК) щурів за умов експериментального коліту. Методи. Розвиток коліту індуковано введенням оцтової кислоти рег rectuт. У СОТК визначено активність NO-синтаз, вміст NO та показники ліпопероксидації. Результати. Одночасне інгібування ЦОГ-2/5ЛОГ сполукою 2 A5DHT суттєвих деструктивних змін у СОТК не спричинило. Активність іNOS знижувалася більш ніж удвічі порівняно з їхньою активністю при коліті. Інтенсивність процесів ліпопероксидації виявилася на значно нижчому рівні, ніж при самостійній дї иелекоксибу чи індометацину. Висновки. Одночасне інгібування ЦОГ-2/5-ЛОГ $2 A 5 D H Т$ справляє виражений цитопротективний ефект у СОТК, що проявляється у зниженні оксидативного стресу та активності NO-синтаз. Вплив сполуки $2 A 5 D H T$ перевищує цитопротективні ефекти селективних і неселективних інгібіторів ЦОГ/ЛОГ, внаслідок чого ї̈ можна використовувати у лікуванні запальних захворювань кишки.

Ключові слова: ииклооксигеназа-2, 5-ліпоксигеназа, оксиди азоту, ліпопероксидація, виразковий коліт.

А. Я. Скляров, Р. Б. Лесик, Н. Б. Панасюк, И. С. Фоменеко, Д. Я. Гаврилюк

Сравнение влияния препаратов двойного действия и традиционных НПВВ на показатели системы NO-синтазы и оксидативного стресса в слизистой оболочке толстой кишки крыс с экспериментальным язвенным колитом

Резюме

Цель. Сравнить влияние соединения 2A5DHT (ингибитора ЦОГ-2/5-ЛОГ) и действие традиционных нестероидных противовоспалительных препаратов на показатели NO-синтазной системы и интенсивность оксидативного стресса слизистой оболочки толстой кишки (СОТК) крыс при экспериментальном колите. Методы. Розвитие колита моделировали введением уксусной кислоты per rectuт. В СОТК определяли активность NO-синтаз, содержание NO и показатели липопероксидации. Результаты. Одновременное ингибирование ЦОГ- 
2/5-ЛОГ соединением 2А5DНТ выраженных деструктивних изменений в COTK не вызвало. Активность іNOS снижалась болем чем вдвое по сравнению с их действием при колите. Интенсивность процессов липопероксидации была значительно ниже, чем при самостоятельном влиянии целекоксиба или индометацина. Выводы. Одновременное ингибирование ЦОГ-2/ 5-ЛОГ 2А5DНТ имеет выраженный ичтооротекторный эффект в СОТК, проявляющийся в снижении оксидативного стресса и активности NO-синтаз. Влияние 2A5DHT превышает цитопротекторное действие селективных и неселективных ингибиторов ЦОГ/ЛОГ, вследствие чего его можно использовать в лечении воспалительных заболеваний кишки.

Ключевые слова: ичклооксигеназа-2, 5-липоксигеназа, оксиды азота, липопероксидация, язвенный колит.

\section{REFERENCES}

1. LeDuc L. E., Su K. C., Guth E., Reedy T., Guth P. H. Effects of cyclooxygenase and lipoxygenase inhibition on eicosanoids and healing of acetic acid colitis in rats // Dig. Dis. Sci.-1993.-38, N 2.-P. 289-294.

2. Tanaka A., Hase S., Miyazawa T., Ohno R., Takeuchi K. Role of cyclooxygenase (COX)-1 and COX-2 inhibition in nonsteroidal anti-inflammatory drug-induced intestinal damage in rats: relation to various pathogenic events // J. Pharmacol. Exp. Ther.2002.-303, N 3.-P. 1248-1254.

3. Haworth R., Oakley K., McCormack N., Pilling A. Differential Expression of COX-1 and COX-2 in the gastrointestinal tract of the rat // Toxicol. Pathol.-2005.-33, N 2.-P. 239-245.

4. Bertolini A., Ottani A., Sandrini M. Dual acting anti-inflammatory drugs: a reappraisal // Pharmacol. Res.-2001.-44, N 6.P. 437-450.

5. Salvemini D., Misko T. P., Masferrer J. L., Seibert K., Currie M. $G$., Needleman $P$. Nitric oxide activates cyclooxygenase enzymes // Proc. Natl Acad. Sci. USA.-1993.-90, N 15.-P. 72407244.

6. Martel-Pelletier J., Lajeunesse D., Reboul P., Pelletier J. P. Therapeutic role of dual inhibitors of 5-LOX and COX, selective and non-selective non-steroidal anti-inflammatory drugs // Ann. Rheum. Dis.-2003.-62, N 6.-P. 501-509.

7. Geronikaki A. A., Lagunin A. A., Hadjipavlou-Litina D. I., Eleftheriou P. T., Filimonov D. A., Poroikov V. V., Alam I., Saxena $A$. $K$. Computer-aided discovery of anti-inflammatory thiazolidinones with dual cyclooxygenase/lipoxygenase inhibition // J. Med. Chem.-2008.-51, N 6.-P. 1601-1609.

8. Myers B. S., Martin J. S., Dempsey D. T., Parkman H. P., Thomas R. M., Ryan J. P. Acute experimental colitis decreases colonic circular smooth muscle contractility in rats // Am. J. Physiol.-1997.-273, 4 Pt 1.-P. G928-936.

9. Morris G. P., Beck P. L., Herridge M. S., Depew W. T., Szewczuk M. R., Wallace J. L. Hapten-induced model of chronic inflammation and ulceration in the rat colon // Gastroenterology.1989.-96, N 3.-P. 795-803.

10. Green L. C., Wagner D. A., Glogowski J., Skipper P. L., Wishnok J. S., Tannenbaum $S$. R. Analysis of nitrite, nitrite and ISN nitrate in biological fluids // Anal. Biochem.-1982.-126, N 1.P. 131-138.

11. Sumbajev V., Yasinskaya I. M. The influence of DDT on nitric oxide synthase activity in liver, lungs and brain of rats // Modern Probl. Toxycol.-2000.-N 3.-P. 3-7.

12. Alejnikova T. L., Rubtsova G. V., Pavlova N. A. Manuals for practical lessons in biochemistry.-Moscow: Medicine, 2000.$128 \mathrm{p}$.

13. Timirbulatov R. A., Seleznev E. I. Method for increasing the intensity of free radical oxidation of lipid-containing components of the blood and its diagnostic significance // Lab. Delo.-1981.N 4.-P. 209-117.

14. Koroluk M., Ivanova L., Mayorova I., Tokorev W. Method of determination of catalase activity // Lab. Techniq.- 1988.-N 1.P. 16-19.

15. Chevari S., Andyal T., Shtrenger Ya. Determination of blood parameters and their role for diagnostics in elderly age // Lab. Delo.-1991.-N 10.-P. 9-13.

16. Sklyarov O. Ya., Panasyuk N. B., Dzhura O. R. Role of NO-synthase system and lipoperoxydation processes in the cytoprotective mechanisms in the condition of ulcerative colitis // Exp. and Clin. Physiol. and Biochem.-2009.-N 1.-P. 38-45.

17. Wallace J. L., Reuter B. K., McKnight W., Bak A. Selective inhibitors of cyclooxygenase-2: are they really effective, selective and GI-safe? // J. Clin. Gastroenterol.-1998.-27, N 1.-P. S2834.

18. Takeuchi K., Yokota A., Tanaka A., Takahira Y. Factors involved in upregulation of inducible nitric oxide synthase in rat small intestine following administration of nonsteroidal anti-inflammatory drugs // Dig. Dis. Sci.-2006.-51, N 7.-P. 12501259.

19. Takeuchi K., Tanaka A., Ohno R., Yokota A. Role of COX inhibition in pathogenesis of NSAID-induced small-intestinal damage // J. Physiol. Pharmacol.-2003.-54, N 4.-P. 165-182.

20. Okayama M., Hayashi S., Aoi Y., Nishio H., Kato S., Takeuchi $K$. Aggravation by selective COX-1 and COX-2 inhibitors of dextran sulphate sodium (DSS)-indused colon lesions in rats // Dig. Dis. Sci.-2007.-52, N 9.-P. 2095-2103.

21. Reuter B. K., Asfaha S., Buret S., Sharkey K. A., Wallace J. L. Exacerbation of inflammation-associated colonic injury in rat through inhibition of cyclooxygenase-2 // J. Clin. Invest.1996.-98, N 9.-P. 2076-2085.

22. Martin A. R., Villegas I., Alarcon de la Lastra C. The COX-2 in- hibitor, rofecoxib, ameliorates dextran sulphate sodium induced colitis in mice // Inflamm. Res.-2005.-54, N 4.-P. 145-151.

23. Singh V. P., Patil C. S., Jain N. K., Singh A., Kulkarni S. K. Ef-fect of nimesulide on acetic acid- and leukotriene-induced in- flammatory bowel disease in rats // Prostaglandins Other Lipid Mediat.-2003.-71, N 3-4.-P. 163-175.

24. Turkevych N. M., Vvedenskij V. M., Petlichnaya L. P. Method of synthesis of pseudothiohydantoin and 2,4-thiazolidinedione // Ukr. Khim. Zhur.-1961.-27.-P. 680-681. 